\title{
The identification of global strategic shipping pivots and their spatial patterns
}

\author{
WANG Chengjin ${ }^{1,2,3}$, CHEN Peiran ${ }^{1,2,3}$, CHEN Yunhao ${ }^{1,2,3}$ \\ 1. Key Laboratory of Regional Sustainable Development Modeling, CAS, Beijing 100101, China; \\ 2. Institute of Geographic Sciences and Natural Resources Research, CAS, Beijing 100101, China; \\ 3. College of Resource and Environment, University of Chinese Academy of Sciences, Beijing 100049, China
}

\begin{abstract}
In concert with developments in global trade and energy resource transportation, there has been a marked increase in reliance on overseas shipping. Unimpeded marine transportation has therefore become a key issue which influences national maritime interests including the security of trade and energy resources. A strategic shipping pivot thus performs a vital controlling function for global shipping networks. In this study strategic shipping pivots are defined and subdivided into sea hubs, channels and areas. We then develop a model to identify strategic shipping pivots on a global scale. The results show that, depending on differences in location, function, and type, the concept of strategic shipping pivot permits the identification of both spatial and structural differentiation with respect to strategic hubs, corridors, and seas. Now 44 strategic hubs have formed across the globe. These hubs have become the control centers of local shipping network organization. At the same time, seven strategic corridors containing most shipping routes and transportation capacity connect important sea areas, and permit a high-degree of control over the transport of strategic materials. The strategic seas, the Caribbean, the Mediterranean, Southeast Asia, and the Pacific provide vital import and export pathways, so that the formation of strategic shipping pivots is mainly influenced by factors such as physical geographical conditions, the spatial distribution of socio-economic activities, business organization, technical progress, geopolitical patterns and geopolitical disputes. Physical geographical conditions provide the potential foundations for strategic shipping pivots, while the spatial distribution of socio-economic activities and communications determine the strategic value of these points. Finally, business organization, technical progress, and geopolitical disputes all function to strengthen the strategic mechanisms and the mutagenicity of strategic shipping pivots.
\end{abstract}

Keywords: strategic shipping pivot; identification model; spatial patterns; mechanisms of development

\section{Introduction}

The trade links between countries around the world have become closer and regional

Received: 2018-01-04 Accepted: 2018-03-20

Foundation: The Strategic Priority Research Program of the CAS, No.XDA20010101; National Natural Science Foundation of China, No.41571113; The Key Project of the Chinese Academy of Sciences, No.ZDRW-ZS-2017-4

Author: Wang Chengjin, PhD and Professor, specialized in economic geography, especially the port system, logistics network, and industrial geography. E-mail: wangcj@igsnrr.ac.cn 
boundaries have been broken down by the growth of marine transportation as a function of global economic development. Marine transportation plays a dominant role in international trade, and therefore occupies a key position in global freight transportation. Statistics show that more than $80 \%$ of exported goods and more than $90 \%$ of strategic materials (e.g., oil and iron) are transported by sea (Ge, 2006). This situation has seen the development of extensive global sea lanes and complex shipping networks in which particular locations have become strategic pivots and play a critical role in controlling the organization and operation of global shipping networks.

Numerous researchers have paid close attention to these strategic pivots, and have analyzed their strategic significance, spatial patterns, and geopolitical value from different angles and in the context of different fields. As the 'commanding heights' of shipping networks, hub ports have been paid considerable attention. Some scholars have studied the formation, evolution and functioning of hub ports and their spatial distribution (Slack, 1990; An et al., 2010), while others have looked more deeply at scale economies and competition between hub ports (Cullinance, 2000; Baird, 2005; Song, 2002). Many scholars have focused on the role of waterway transportation systems in integrating global resources, and the consequent importance of the smooth development of such routes for the development of major countries and regions. Some research examined the quantity, distribution and feature of maritime strategic channels (Zhao, 1998; Li, 2010; Zheng, 2012; Liang et al., 2014; Du et al., 2014; Wang, 2015; Liang, 2016). While some research constructed a corridor appraisal model based on the corporate strategy concept of resource and capability appraisal to evaluate the corridors (Fraser et al., 2014).

Other scholars examined empirically the influence of specific shipping channels, such as the Carat Canal, Strait of Hormuz, the Panama Canal, on energy transport and the shipping market (Yang, 2006; Cai, 2008; Li, 2010; Shi et al., 2013; Sun, 2013).

The identification of strategic pivots, however, has rarely been noted, and scholars have relied on qualitative analyses, even though Wang (2008) identified a number of hub ports based on global container movements and sailing schedules. Although existing research has paid close attention to the distribution and strategic value of hub ports and shipping channels, no systematic analysis has been carried out from the point-of-view of strategic shipping pivots. As a result the question as to how to identify and construct these important loci is a key academic issue. This paper therefore aims to define systematically the scientific concept of a strategic shipping pivot, design a mathematical model to identify them, and analyze their global spatial distribution and the factors controlling this distribution.

At present, global shipping network comprises three trunk routes which link the Far East, North America and Europe, namely, the Far East-Europe/the Mediterranean, North America-Europe/the Mediterranean and the Far East-North America routes. With the development of Chinese ocean trade from the mid-1990s, trade routes involving China became increasingly important, with in particular the Far East-Europe/the Mediterranean route becoming the one with the highest transport capacity and volume. This route coincides with the spatial trajectory of Chinese Maritime Silk Road, reflecting the core position of the Chinese Maritime Silk Road in the global shipping network. The Belt and Road Initiative is the main mechanism through which China plans to develop a comprehensive globalization strategy, the mechanism will promote the infrastructural foundations to secure and solidify 
China's relations with countries along the Silk Roads (Liu et al., 2016; Su, 2016; Bennett, 2016), with the construction of the Maritime Silk Road further emphasizing China's control of global shipping resources. The identification and development of a variety of maritime strategic pivots will play an important part in increasing China's global maritime role and contribute to the restructuring of global governance structures.

\section{Concepts and methods}

\subsection{Definition of strategic shipping pivots}

A pivot is a common term in academic circles. Used to refer to a fixed point on which something turns, the term has been extended to refer to a person, place, thing or factor that has a major or central role in designing, guiding, supporting and shaping what happens. In this study, a strategic shipping pivot is defined as a location which both controls and contains a shipping organization and therefore plays a critical role in the network. Whether it functions normally or acts to deal with difficulties in the operation of a shipping network, a pivot is always located at the end of most routes. As a result a convergence of their interests has great strategic value from both economic and security perspectives.

Shipping management includes route organization and configuration, ship navigation and dispatch, freight distribution and transfer, and shipping escort and supply. The concept of location is complex, involving multiple concepts, spatial morphology, and even functional structure, and can change with changes in spatial scale and the size of a focused problem. In this paper, location is used to refer to points (ports), lines (shipping channels), and areas (navigation area).

The coverage of a strategic shipping pivot changes with changes in spatial scale. From the perspective of economic geography, the spatial aspects of strategic shipping pivots can be divided into strategic shipping hubs, channels, and sea areas. A strategic shipping hub tends to be a port node with central effect and in a dominant position. These ports are the 'commanding heights' of shipping networks, acting as strategic pivot point and as the locations that 'join and establish contacts between' numerous routes and that 'distribute and recombine' goods. Strategic shipping channels are channels that exercise controlling effects and are mostly narrow sea transport areas and strait hubs or canal channels used as parts of numerous international 'bundling and folding' voyage routes and 'centralized channels' for cargo ships. Similarly, strategic shipping sea areas refer to large zones, comprising many islands, numerous straits, and fragmented sea regions in which there are numerous optional routes with dense traffic on central axes. Numerous mutually influencing combinations exist between strategic shipping hubs, channels, and sea areas.

\subsection{Data and sample}

A strategic shipping pivot is not a spatial concept with a single constitution as there are a number of different types and their scientific connotations, spatial morphologies, and functional structures also vary. Three types of strategic shipping pivot were identified using different methods, data types, and research samples. In the first place, strategic shipping hubs were identified by selecting of ports with strategic significance (selecting hub ports from all ports). To identify shipping hubs this study drew on existing research and used a shipping 
network organizational evaluation model and first contact degree, the research sample covers more than 500 ports around the world. Three types of indicators, i.e., the data of port organizational ability, network accessibility and radiation ability, were selected from the sailing schedules or ship operational timetables for the major global shipping companies. More specifically, routes were selected on a monthly basis between September 1st, 2016 and September 31, 2016. This paper used the data of sailing schedules to analyze ports' organizing ability and strategic value, concentrating on process analysis of enterprise behavior and transport organization (Cullinane et al., 2000; Veenstra et al., 2005; Notteboom, 2006). To fully reflect global shipping organizational patterns, the original data was derived from the official website of each shipping company that included 12 major liner companies. These companies accounted for about $60 \%$ of global freight volume. Production capacity index used global container throughput in 2010 as analysis data, and the throughput unit is TEU. Second, to identify shipping strategic channels (major global straits and canals), an index evaluation method was applied. The basic parameters including waterway depth and waterway width were derived from data available on the internet. The freight transportation and the throughput data of ships is provided by the U.S. Energy Information Administration, Lloyd's List Intelligence, and canal authorities. The date of these data for strategic channels is 2013. Third, strategic shipping sea areas were identified as global level-two navigation zones using an index evaluation method. Two types of indexes, i.e., the data of fragmentation degree and geographical condition were obtained from internet, the date of data is 2016. The data of shipping status originated from results of strategic hubs identification in this paper.

\subsection{Identification method and model index}

\subsubsection{Strategic shipping hub}

The organization of shipping generates different connection intensities among ports, and so the type of link reflects the status of a port within a network. A complete connection matrix $(M)$ can be generated by transforming and merging the sailing schedules of liner companies, as in Equation (1). $O_{i j}$ denotes the transportation relationship between port $i$ and port $j, D_{j i}$ the transportation relationship between port $j$ and port $i, R_{i j}$ the sum of the transportation relationships between port $i$ and port $j, O_{i}$ the total transportation relationship between port $i$ and others, and $D_{i}$ the total transportation relationship between others and port $i$. In accordance with the selected primary contact method $\left(L_{i k}\right), L_{i k}$ denotes the primary contact degree of port $i$, while $k$ refers to the primary contact port of port $i$, as follows:

$$
\begin{gathered}
M=\left[L_{i j}\right] 530 \times 530 \\
R_{i}=O_{i}+D_{i}=\sum_{j=1}^{n-1}\left(R_{i j}+R_{j i}\right) \\
L_{i k}=M A X\left[\frac{R_{i j}+E_{j i}}{R_{i}}\right]=M A X\left[\frac{R_{i j}+R_{j i}}{O_{i}+D_{i}}\right] \\
H_{i}=\sum_{i=1, j=1}^{n, m} X_{i j}^{*} \times G_{j}
\end{gathered}
$$


Shipping hubs of different levels and grades exercise different control functions and degrees of control over global shipping networks. To classify hubs, a number of indices representing these functions were used in this study, including port cargo handling capacity, shipping line, flight frequency, the number of access ports, the scale of transportation connections, and the number of primary ports. Of these indices, port cargo handling capacity mainly relates to the production scale of port transportation, while shipping line and flight quantity mainly refer to the shipping organizational ability of a port. The number of access ports and scale of transportation connections mainly reflect the accessibility of an entity within a shipping network, and the number of primary centers mainly reflects the radiation and attraction ability of a given hub port with respect to its counterparts. Once all this primary data was standardized, it was possible to generate a sum based on the weight of each index to obtain the 'hubness' of each port. In the computational method outlined in Equation (4), $G_{j}$ denotes the weight of the $j$ index and $H_{i}$ is the 'hubness' of the $i$ th port (Table 1 ).

Table 1 Indicators used to characterize global strategic shipping pivots

\begin{tabular}{|c|c|c|c|c|}
\hline Hub type & Index & $\begin{array}{c}\text { Evaluation } \\
\text { indicator }\end{array}$ & Weight $G_{i}$ & Notes \\
\hline \multirow{6}{*}{$\begin{array}{l}\text { Strategic } \\
\text { hub }\end{array}$} & Production capacity & Throughput & 0.30 & The production scale of port transportation \\
\hline & $\begin{array}{l}\text { Organizational } \\
\text { ability }\end{array}$ & $\begin{array}{l}\text { Shipping line } \\
\text { quantity }\end{array}$ & 0.20 & The organizational capacity of a port \\
\hline & & Liner movements & 0.16 & The vessel berthing frequency of a port \\
\hline & $\begin{array}{l}\text { Network } \\
\text { accessibility }\end{array}$ & $\begin{array}{l}\text { Quantity of access } \\
\text { ports }\end{array}$ & 0.12 & $\begin{array}{l}\text { The accessibility of a port within the } \\
\text { global shipping network }\end{array}$ \\
\hline & & $\begin{array}{l}\text { Transportation } \\
\text { connection scale }\end{array}$ & 0.08 & $\begin{array}{l}\text { The accessibility of a port within the } \\
\text { global shipping network }\end{array}$ \\
\hline & Radiation ability & $\begin{array}{l}\text { Quantity of pri- } \\
\text { mary connections }\end{array}$ & 0.14 & $\begin{array}{l}\text { The radiation and attraction ability of other } \\
\text { ports }\end{array}$ \\
\hline \multirow[t]{4}{*}{$\begin{array}{l}\text { Strategic } \\
\text { channel }\end{array}$} & $\begin{array}{l}\text { Shipping } \\
\text { capacity }\end{array}$ & $\begin{array}{l}\text { Cargo volume } \\
\text { passing through }\end{array}$ & 0.16 & $\begin{array}{l}\text { The level of the port transportation func- } \\
\text { tion }\end{array}$ \\
\hline & $\begin{array}{l}\text { Traffic } \\
\text { restriction }\end{array}$ & $\begin{array}{l}\text { Water depth con- } \\
\text { dition }\end{array}$ & 0.24 & Channel entry difficulty \\
\hline & $\begin{array}{l}\text { Location } \\
\text { condition }\end{array}$ & $\begin{array}{l}\text { Importance of } \\
\text { connecting sea } \\
\text { areas }\end{array}$ & 0.40 & The importance of channel accessibility \\
\hline & & $\begin{array}{l}\text { Shipping substi- } \\
\text { tutability }\end{array}$ & 0.20 & Substitutability of channel accessibility \\
\hline \multirow[t]{3}{*}{$\begin{array}{l}\text { Strategic } \\
\text { sea area }\end{array}$} & $\begin{array}{l}\text { Fragmentation } \\
\text { degree }\end{array}$ & Regime quantity & 0.40 & $\begin{array}{l}\text { The degree of regional regime conver- } \\
\text { gence and fragmentation }\end{array}$ \\
\hline & $\begin{array}{l}\text { Geographical } \\
\text { condition }\end{array}$ & $\begin{array}{l}\text { Number of islands } \\
\text { and straits }\end{array}$ & 0.30 & $\begin{array}{l}\text { The degree of advantage posed by regional } \\
\text { physical geographical location }\end{array}$ \\
\hline & $\begin{array}{l}\text { Shipping } \\
\text { status }\end{array}$ & $\begin{array}{l}\text { Number of hub } \\
\text { ports }\end{array}$ & 0.30 & $\begin{array}{l}\text { The strategic status of a region within a } \\
\text { shipping network }\end{array}$ \\
\hline
\end{tabular}

\subsubsection{Strategic shipping channel}

Globally there are a huge number of straits and canals which vary greatly in length, water depth, navigational value, and strategic significance. More than 100 straits and canals are used by shipping globally, but only about 40 are used for international shipping. The strategic value of shipping channels is reflected in a number of factors. The first is shipping ability which mainly denotes the throughput of goods or ships where higher indices denote greater strategic significance. The second set of indicators include natural water depth and the level or tonnage of ships permitted to enter a given location, while a natural attribute index including channel depth also includes water width of individual channels. In this case, 
strategic significance increases as water depth decreases, as the size of permitted ship falls and network restrictions accordingly increase. The third index reflects strategic significance in the transportation of certain materials, including iron ore, oil, and coal. In some cases the concept of ship throughput quantity was introduced to support the analysis, as strategic status will increase as the values for this index increase. The fourth index used in this study is comprehensive and refers to locational conditions including the importance of a region or sea area connected with a channel. In this way attention was paid to whether or not a channel connects with an important navigation area or economic region. In this context, the degree of substitution connectivity was mainly investigated via the quantity of comparable channels. In this case strategic value decreases as the number of substitutable channels increases. A strategic value score was computed as follows:

$$
S=f\left(S_{1}, S_{2}, S_{3}, S_{4}\right)
$$

where $S_{1}, S_{2}, S_{3}$ and $S_{4}$ denote the natural quality, the volume of cargo or ships, the throughput of strategic materials and locational conditions, respectively. An analytical hierarchy process (AHP) was used to determine the weight of each index and to standardize the data, and the strategic value score was computed as a weighted sum of the four indicators (Table 1).

\subsubsection{Strategic shipping sea area}

To identify strategic sea areas the number of regimes, islands and straits and the number of hub ports were computed. Regime quantity is an indicator of the degree of political and regulatory convergence and fragmentation of a navigation area. The greater the number of regimes which reflects the fragmentation degree of power pattern the more intense will regional competition be and the easier will it be for external forces to enter a zone. The quantity of islands and straits reflects the physical geography of a navigational area. The more there are the more ports will be developed, enhancing the controllability of shipping routes, and making shipping more selective. The quantity of hub ports reflects the status of a navigational area within a global shipping network. A strategic shipping area score was accordingly computed as follows:

$$
D=f\left(D_{1}, D_{2}, D_{3}\right)
$$

where $D_{1}, D_{2}$ and $D_{3}$ denote the number of regimes, islands and straits, and hub ports, respectively. To determine the weight of each index, an AHP was used and the strategic value score for each sea area was computed as a weighted sum of the three indicators (Table 1).

\section{Identification of strategic shipping pivots and their spatial patterns}

\subsection{Strategic shipping hubs}

A shipping strategic hub tends to be a port node in a dominant position that occupies the 'commanding heights' over a shipping network. Shipping hubs are therefore located mostly within important sea hub areas and must be passed through by the main global shipping vessels. These hubs therefore comprise numerous trunk and straight lines, are characterized by substantial throughput, occupy a high proportion of sites regionally or globally, control the spatial organization of the global shipping network, and deeply influence the operation of the international market.

Applying this approach 44 strategic global hubs were identified (Figure 1). These hubs 


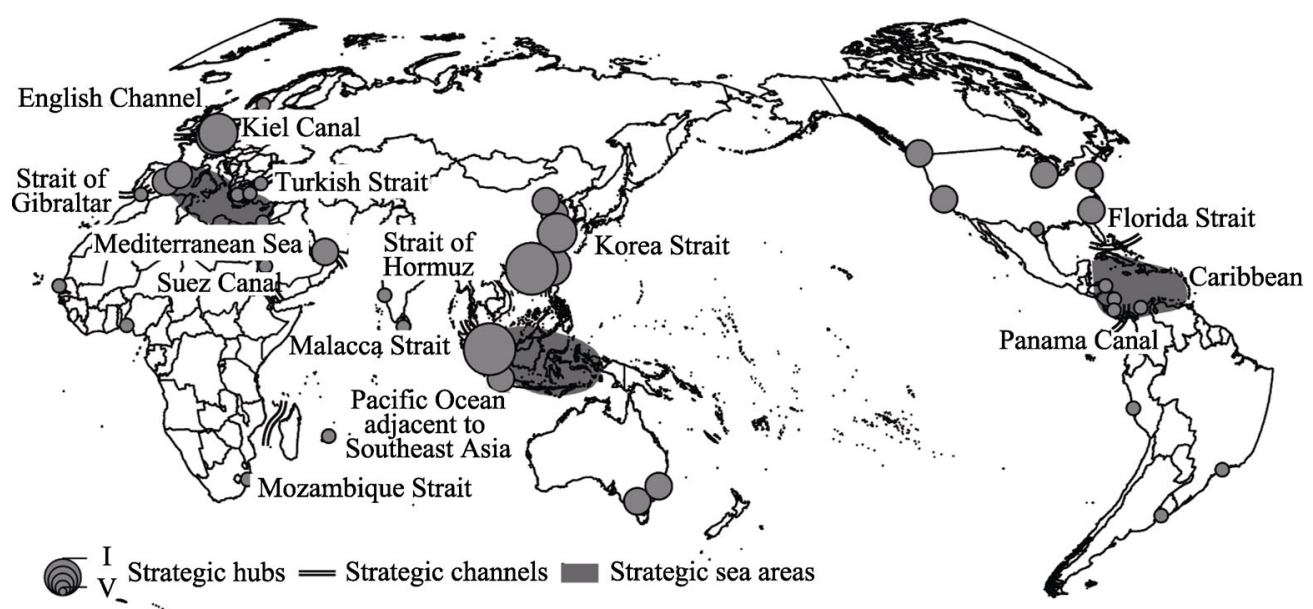

Figure 1 Spatial pattern of global strategic shipping pivots

included Antwerp, Rotterdam, and Oslo in the northwest European navigational area, Valencia, Barcelona, Piraeus, Izmir, Ashdod, Istanbul, and Algeciras in the Mediterranean Sea navigational area, Dubai, Jeddah, Colombo, and Delhi in the Middle Eastern and South Asia navigational area, Singapore and Jakarta within the Southeast Asian navigational area, Hong Kong, Shenzhen, Kaohsiung, Tokyo, Busan, Shanghai, Tianjin, and Qingdao in the East Asian navigational area, Durban and Louis in the African east coast navigational area, Dakar and Lagos in the African west coast navigational area, Melbourne, Sydney, and Levin in the Australia-New Zealand (ANZ) navigational area, Chicago, New York, Charleston, Ketesier, and Limon within the North American east coast navigational area, Vancouver, Oakland, and Manzanilla in the North American west coast navigational area, Cartagena, Santos, and Montevideo in the South American east coast navigational area, and Callao and San Antonio in the South American west coast navigational area. These strategic hubs all have a dominant status and influence within each navigational area.

These results show that the general distribution of strategic shipping hubs shares a number of characteristics. First, these hubs exhibit obvious features of regionalization as there are always two or more in the same navigational area, and they are more abundant in the East Asian and Mediterranean Sea navigational areas. Influenced by land-sea patterns, most coastlines extend lengthwise north and south, and so the relative layout of two adjacent shipping hubs always encompasses the same coastline. Second, shipping hubs tend to have obvious adjacent layouts and exhibit prominent dual-hub phenomena, as they are formed under common natural and hinterland conditions, but are more affected by differences in port interests, especially those associated with differences in national political systems when two adjacent shipping hubs belong to two distinct countries. Third, hubs within regions of navigational areas tend to exhibit diversification patterns as each develops its own service area or hinterland. This phenomenon is seen markedly within the Mediterranean Sea, East Asian, and Caribbean navigational areas, while shipping markets and regimes within marine fragmentation zones tend to be relatively scattered, leading to the formation of numerous small-scale shipping markets and strategic hubs and an associated diversification of port interests. Fourth, just a handful of ports comprise high-grade shipping hubs and most occupy lower positions in the hierarchy. Shipping hubs can in fact be divided into five grades/ 
classes with two in the first, two in the second, and four in the third. These eight account for almost $18.6 \%$ of the total. Most high-grade shipping hubs fall in the fourth (14 hubs) and fifth (21 hubs) categories (Table 2). Of high-grade shipping hubs, most are in East Asia. These hubs have an absolute advantage in terms of grade and location in the area in which high-grade shipping hubs are concentrated. Eight of these hubs were in the first three grades, while five were located in East Asia and six in Asia-Pacific, an obvious spatial agglomeration. Relatively few high-grade hubs are found in North America and Europe. Hubs in North America, the Middle East, and ANZ are mostly fourth grade. In the Mediterranean Sea as well as in the Central, South American, and African navigational areas, the grade of hubs tends to be very low with most in the fifth category. High-grade hubs are influenced by pendulum line spatial organization and so are mostly distributed along east-west trade routes. It is also clear that first and second grade strategic hubs have global significance, while lower-grade hubs are mainly international or regional, no matter which grade. Strategic hubs all exert central control effects on the organization of shipping networks in areas where they are located and are therefore also strategic pivots.

Table 2 The hierarchical structure of strategic shipping hubs

\begin{tabular}{cccl}
\hline Grade & \multicolumn{1}{c}{ Score } & Number of ports & \multicolumn{1}{c}{ Port name (score) } \\
\hline 1 & $1 \geqslant H_{i} \geqslant 0.8$ & 2 & Singapore (0.975), Hong Kong (0.87) \\
2 & $0.8>H_{i} \geqslant 0.6$ & 2 & Shanghai (0.671), Shenzhen (0.652) \\
3 & $0.6>H_{i} \geqslant 0.4$ & 4 & $\begin{array}{l}\text { Antwerp (0.537), Busan (0.501), Kaohsiung (0.491), Rotter- } \\
\text { dam (0.473) }\end{array}$ \\
& & New York (0.359), Qingdao (0.322), Tokyo (0.293), Charleston \\
4 & $0.4>H_{i} \geqslant 0.2$ & 14 & $(0.292)$, Dubai (0.278), Jakarta (0.265), Valencia (0.25), Oak- \\
& & & land (0.248), Melbourne (0.246), Chicago (0.23), Barcelona \\
& & $(0.228)$, Tianjin (0.225), Sydney (0.223), Vancouver (0.203) \\
& & & Santos (0.199), Jeddah (0.187), Colombo (0.183), Manzanilla \\
& & & $(0.159)$, Istanbul (0.15), Oslo (0.132), Cartagena (0.124), Al \\
& & & Hera Heath (0.122), Callao (0.117), Piraeus (0.113), Montevi- \\
& & & deo (0.102), Louis (0.098), Limon (0.082), Durban (0.080), \\
& & San Antonio (0.076), Costel (0.074), Delhi (0.072), Izmir \\
& & $(0.072)$, Lagos (0.031), Ashgabat0.019), Dakar (0.016)
\end{tabular}

\subsection{Strategic shipping channels}

A strategic shipping channel is a strait or linear navigable canal within a shipping network. A channel comprises an aggregation of hubs (points) and is always referred to as a marine transportation channel. Globally there are around 50 well-known straits out of a of more than 1,000, and all have different degrees and types of strategic significance. Applying the recognition model discussed above, channels of globally important shipping value were identified and included the Malacca Strait, the Strait of Gibraltar, the Dover Strait, the Strait of Hormuz, the Strait of Mandeb, the Florida Strait, the Dardanelles, the Strait of Bosphorus, the Korean Strait, the Mozambique Strait, the Suez Canal, the Panama Canal, and the Kiel Canal (Figure 1). Of these straits the Malacca Strait had the highest shipping value (0.942), while those of secondary importance were the Suez Canal, the Panama Canal, and the Strait of Hormuz that all had shipping values greater than 0.83 (Table 3 ).

The comprehensive analysis presented in this study shows that strategic shipping channels exhibit a number of shared features. First, a shipping channel is always a narrow waterway that connects two navigational areas and is the minimum navigable path. The Malacca Strait, 
for example, connects East Asia with the Indian Ocean navigational area, while the Suez Canal connects the Indian Ocean with the Mediterranean Sea, the Panama Canal connects the Pacific Ocean with the Atlantic, the Gibraltar Strait connects the Mediterranean with the Atlantic, and the Strait of Mandeb connects the Red Sea with the Gulf of Aden and, along with the Suez Canal, controls the shipping organization between the Indian Ocean and Mediterranean Sea, while the Kiel Canal connects the North Sea with the Baltic Sea, and the English Channel connects the Atlantic with the North Sea.

Table 3 Key indicators of strategic shipping channels

\begin{tabular}{|c|c|c|c|c|c|c|}
\hline Strait & $\begin{array}{c}\text { Water } \\
\text { depth } \\
\text { (m) }\end{array}$ & $\begin{array}{l}\text { Width } \\
(\mathrm{km})\end{array}$ & $\begin{array}{l}\text { Vessel traffic } \\
\text { (thousands of } \\
\text { ships/year) }\end{array}$ & $\begin{array}{l}\text { Oil throughput } \\
(10,000 \text { bar- } \\
\text { rels/day) }\end{array}$ & $\begin{array}{l}\text { Strategic } \\
\text { value }\end{array}$ & Connected sea areas \\
\hline Malacca Strait & 25 & 37 & 8 & 1,520 & 0.942 & $\begin{array}{l}\text { Indian Ocean, South China Sea, } \\
\text { and Pacific Ocean }\end{array}$ \\
\hline Strait of Hormuz & 10.5 & 56 & 4 & 1,700 & 0.840 & Persian Gulf and Arabian Sea \\
\hline English Channel & 60 & 34 & 20 & - & 0.805 & North Sea and Baltic Sea \\
\hline $\begin{array}{l}\text { Strait of } \\
\text { Gibraltar }\end{array}$ & 300 & 14 & 12 & - & 0.851 & Mediterranean and Atlantic \\
\hline $\begin{array}{l}\text { Strait of } \\
\text { Mandeb }\end{array}$ & 150 & 26 & 2 & 380 & 0.743 & $\begin{array}{l}\text { Red Sea, Mediterranean, and } \\
\text { Indian Ocean }\end{array}$ \\
\hline Suez Canal & 22.5 & 34 & 2 & 320 & 0.853 & $\begin{array}{l}\text { Mediterranean Sea and Indian } \\
\text { Ocean }\end{array}$ \\
\hline Panama Canal & 13 & 152 & 1.5 & 87.7 & 0.838 & Pacific and Atlantic \\
\hline
\end{tabular}

Second, data show that water depth conditions contribute significantly to both the importance and strategic value of shipping channels. Based on the data of 2013, the water depth of the Panama Canal, for example, is 13 meters, while allowable ship tonnage is 760 million tons and the allowable draft depth of a vessel is less than 12 meters. In contrast, the water depth of the Suez Canal is 22.5 meters, and the maximum allowable draft depth of a ship is 18.9 meters, while the width at the narrowest point across the Strait of Hormuz is just 10.5 meters and the mean water depth is 70 meters, exerting an influence on ship size. As the water depth of the Kiel Canal is just 11 meters, Panamax and Suezmax ships are the largest capable of passing through these two canals (Panama Canal and Suez Canal). Capesize ships can pass neither through the Panama Canal nor the Suez Canal because of scale restrictions and so must detour via the Cape of Good Hope and Cape Horn (data of vessel types came from internet). These canals restrict the entry of ships as a result of their water depth. Amongst the straits considered in this paper only the Strait of Hormuz is relatively shallow. Cannel width has become an important factor restricting the entry of ships; the Suez Canal is just 34 meters wide, for example (Table 4).

Third, it is clear that shipping channels are the dominant focus of maritime traffic and play a major role in global route organization, exerting obvious control over the transportation of strategic materials. The freight throughput of the Malacca Strait, for example, accounts for between $20 \%$ and $25 \%$ of global traffic as more than 50,000 ships pass through each year (2003). This figure includes more than $25 \%$ of all the tankers in the world, as is the only route for oil to be shipped from the Middle East and Africa to Asia, making it the 'crossroads' of Southeast Asia. Similarly, the Strait of Hormuz plays a major role in global petroleum transport; a total of 13.4 million barrels of crude oil pass through each day, 
Table 4 Hierarchical structure of vessel types for major shipping channels

\begin{tabular}{llccc}
\hline \multicolumn{1}{c}{ Ship type } & \multicolumn{1}{c}{ Grade } & Width (m) & $\begin{array}{c}\text { Load (dead weight } \\
\text { tonnage (dwt) }\end{array}$ & Draft (m) \\
\hline Tanker & Panamax & 32.3 & $6-7.5$ & 12 \\
& Aframax & $41-44$ & $8-12$ & 14 \\
Container ship & Suezmax & 70 & $12.5-17$ & 21.3 \\
& Panamax & 32.3 & 5 & 11 \\
& post-Panamax & 42.8 & 10 & 13.5 \\
Bulk cargo ship & Suezmax & 55 & 13.7 & 13.5 \\
& post-Suezmax & 60 & 20 & 13.7 \\
& Panamax & 26 & $5-8$ & 17.3 \\
\hline
\end{tabular}

equivalent to one tanker every eight minutes on average. This strait provides a route for $60 \%$ of the oil supply to the west and is often referred to as the 'offshore oil passage throat' (from Energy Information Administration in 2010). At the same time, 15,000 ships pass through Panama Canal annually, and the trade volume of this passage amounts for $5 \%$ of the global total (2014), while the Suez Canal is the busiest in the world, accounting for $70 \%$ of all the petroleum that is shipped from the Middle East to Western Europe and for $14 \%$ of total global freight throughput (2014). The traffic that passes through the Strait of Gibraltar accounts for $25 \%$ of global ship moments. As more than 120,000 vessels pass through annually, this strait is referred to as the 'lifeline of the western World'. Similarly, the navigation density of the Kiel Canal is 123 ships per day on average, a freight throughput that equates to nine million tons per month (2006), while 5,000 ships pass through the English Channel each day.

Fourth, strategic shipping channels have become a focal point for global military and geopolitical struggles; there are many examples of countries starting wars, some of which lasted more than 100 years, over the possession of a strategic channel. Japan and the USA exert profound influence on the Malacca Strait. The Strait of Gibraltar is controlled by the UK even though it belongs to Spain. The USA has controlled the Panama Canal for more than 100 years and still provides it with military protection, and the UK maintained a military presence along the Suez Canal between the 1880s and the1950s.

Fifth, the Malacca Strait and the Suez Canal both have the highest global strategic significance, not only because they control container transportation between the Far East and Europe, but also because they control petroleum transportation from the Middle East to East Asia and between the Middle East and western Europe, respectively. At the same time, the Malacca Strait also plays a major role in iron ore transportation from Brazil and Australia to China, Japan, and South Korea, while the Panama Canal controls container transportation from the Far East to the east coast of North America. Similarly, ships must pass the Strait of Hormuz to transport oil from the Middle East to the rest of the world, and the Strait of Gibraltar controls petroleum transportation between the Middle East and Western Europe as well as container transportation between the Far East and Europe. The respective strategic significance of the Mandeb and Mozambique straits have decreased over time in small increments because of their good water depth conditions and wide water surface. These two 
passages still exert controlling effects on petroleum transportation from the Middle East to Europe. Finally, while the Kiel Canal has regional significance, it exerts less of an influence on intercontinental shipping.

Sixth, a number of additional areas also warrant attention in addition to the strategic channels discussed above. The Strait of Sunda, the Strait of Makassar, and the Strait of Lombok, for example, are all within the Southeast Asian sea area; the first of these forms a strategic channel between the Pacific and the Indian Ocean, while the Strait of Lombok has become a route for super large ships, especially tankers, with load of more than 200,000 tons that navigate between the Pacific and Indian Oceans. These straits have become the main route for iron ore and coal shipped from Australia to China as well as for the movement of oil and iron ore from the Middle East to Japan and South Korea. A number of other strategic channels are also still under construction and include the Thailand Carat Isthmus Canal and the Nicaragua Canal; as the water depth of the former is 25 meters, this passage will impact on the shipping capacity of the Malacca Strait if successfully completed, while the water depth of the Nicaragua Canal will reach 27.6 meters. It is possible that the latter will take the place of the Malacca Strait as the main channel connecting the Atlantic and the Pacific.

\subsection{Strategic shipping areas}

The concept of a strategic shipping area refers to an ocean area of crucial strategic significance. These areas are of special global importance, comprising global shipping hubs and places where multiple forces intersect and crisscross one another. Applying the recognition method, the main sea areas identified included: the Sea of Japan, the Crimson Sea, the Arabian Sea, the Bay of Bengal, the Bay of Mexico, the Persian Gulf, the Caribbean, the Black Sea, the Mediterranean Sea, the North Sea, The Baltic, and the South China Sea (Figure 1). The Mediterranean Sea, the Pacific Ocean adjacent to Southeast Asia, and the Caribbean all comprise particularly important strategic sea areas with values of $0.885,0.754$, and 0.735 , respectively. Data show that these areas share a number of characteristics. The first of which is that they are always located in zones that must be navigated by shipping connections between globally developed areas. These areas are usually in important travel areas or are intersections between key economic regions. Thus, the Mediterranean Sea is located at the intersection between Asia, Africa, and Europe, while the Pacific Ocean adjacent to Southeast Asia comprises components of the North and South Pacific as well as the intersection between the Pacific and Indian Oceans. Similarly, the Caribbean is located at the intersection between the important economic zones of North and South America.

Secondly, strategic shipping sea areas are more often than not connected, close to, or covered by a number of strategic shipping channels and important strategic shipping hubs: strategic sea areas to some extent include strategic shipping channels and hubs. There are six important straits and four strategic hubs in the Caribbean, including for example the Panama Canal, while the Mediterranean Sea contains nine straits and seven strategic hub ports and boasts the Suez Canal and the Strait of Gibraltar as its main maritime channels. Similarly, the Pacific Ocean adjacent to Southeast Asia encompasses 11 straits and five hub ports with the Malacca Strait and the port of Singapore as its main maritime channel and core strategic hub.

Third, the data collected in this study show that strategic shipping areas also tend to be 
regions in the world where the most routes and ships pass. These regions are therefore characterized by dense route organization and huge shipment volumes. More than 2,000 ships pass through the Mediterranean Sea each day, accounting for about $85 \%$ of all the oil destined for western Europe (2007), while the Pacific Ocean adjacent to Southeast Asia must be navigated by all westbound traffic from China and so this area plays a strategic role in the sea routes from eastern and western Asia to Europe, Australia, and North America, accounting for $30 \%$ of global trade volumes and $50 \%$ of petroleum traffic volumes (2011).

Fourth, strategic shipping areas also tend to include numerous islands and therefore form fragmented oceans; in other words, these sea areas are broken up into smaller parts that often provide numerous naturally good ports. These phenomena are also clearly seen in the three sea areas identified by this study. This situation creates more choices of shipping routes and makes the relationships between route organization, port construction, and shipping more complex.

Fifth, the number of countries located within strategic sea areas also tends to be relatively high while these nations also tend to exhibit a relatively weak and uneven level of development of regulatory regimes underpinned by divisions of state power between countries. As shown in Table 5, 11 countries and regimes are located in the Pacific Ocean adjacent to Southeast Asia, while there are more than 20 nations in the Caribbean, the 'Mediterranean Sea of America'. A total of 19 countries are distributed around the Mediterranean, and are all obvious points of intersection of nations or segmented areas. This spatial feature often leads to marked competition between nations in port construction and shipping organization, especially in the case of hub ports. Nevertheless, the presence of more countries also promotes mutual economic discourse and closer shipping cooperation, while also ensuring a relatively well-developed internal transportation market and spatial network.

Table 5 Key indicators of strategic shipping seas

\begin{tabular}{|c|c|c|c|c|c|}
\hline $\begin{array}{l}\text { Strategic } \\
\text { sea area }\end{array}$ & $\begin{array}{l}\text { Number } \\
\text { of regimes }\end{array}$ & $\begin{array}{l}\text { Number } \\
\text { of straits }\end{array}$ & $\begin{array}{l}\text { Number of } \\
\text { hub ports }\end{array}$ & $\begin{array}{c}\text { Strategic } \\
\text { value }\end{array}$ & Coastal countries and regions \\
\hline Caribbean & 20 & 6 & 4 & 0.735 & $\begin{array}{l}\text { Guatemala, Honduras, Nicaragua, Costa } \\
\text { Rica, Panama, Columbia, Venezuela, Cuba, } \\
\text { Haiti, Dominica, Antigua, Barbuda, Trini- } \\
\text { dad and Tobago }\end{array}$ \\
\hline $\begin{array}{l}\text { Mediterra- } \\
\text { nean Sea }\end{array}$ & 17 & 9 & 7 & 0.885 & $\begin{array}{l}\text { Spain, France, Monaco, Italy, Malta, Slo- } \\
\text { venia, Croatia, Bosnia, Herzegovina, Hesse } \\
\text { Montenegro, Albania, Greece, Turkey, } \\
\text { Cyprus, Syria, Lebanon, Israel, Palestine, } \\
\text { Egypt, Libya, Tunisia, Algeria, Morocco }\end{array}$ \\
\hline $\begin{array}{l}\text { Pacific } \\
\text { Ocean } \\
\text { adjacent to } \\
\text { Southeast } \\
\text { Asia }\end{array}$ & 12 & 11 & 5 & 0.754 & $\begin{array}{l}\text { China, Vietnam, Laos, Cambodia, Thailand, } \\
\text { Myanmar, Malaysia, Singapore, Indonesia, } \\
\text { Brunei, Philippines, East Timor }\end{array}$ \\
\hline
\end{tabular}

\section{The dynamics of strategic pivot formation}

The formation of a strategic pivot is a result of internal mechanisms influenced by a variety of factors including natural, social, enterprise, and technical factors. As all of these factors 
exert an influence, affect different aspects of strategic pivot formation and have effects that vary over time, we conducted an in-depth analysis of four of them: physical geography, socioeconomic distribution, business organization and technical progress, and geopolitical pattern.

\subsection{Physical geography}

Land-sea patterns are the foundation of physical geography and the factor which will exert a long term influence on the formation of strategic pivots. Earth crust movements have led to the formation of global land-sea patterns, and the basic distribution of continents and seas have interacted to form narrow channels and low-lying valleys. Thus, shipping channels formed over time via isthmus creation due to long periods of erosion or when low-lying land areas were submerged by sea. This means that strategic shipping channels and sea areas tend to be located in isthmus areas between continental plates, while the relative locations of rivers and oceans determine the natural locations and layouts of ports. The shipping value of a river flowing into the sea is therefore higher than that of a continental river flowing into a lake, giving river estuaries a unique strategic value. This advantage derives from the locational advantages afforded by coordinated transport arrangements connecting offshore ocean and inland routes and the creation of the conditions for the development of large ports. A number of strategic hubs are estuary ports, including Rotterdam and Shanghai, where the influences of location and hinterland will likely exist over a long period.

Coastal geological conditions also determine the natural background for port development; different coastlines have variable natural attributes and technical engineering characteristics which determine their suitability for port construction. Hilly coasts, for example, are suitable for the construction and development of ports, especially harbor coasts which exhibit an extrusive marine foreland, embedded bays, hard geology, and deep pre-bank waters. Most strategic hubs are located on shorelines that exhibit good geological conditions, including natural water depths and wide water surfaces, as these exert marked influence on their strategic shipping value. The shallower the natural water and channel, the smaller the ship that will be able to pass through or be anchored, and the greater the restrictions on the shipping network, and so the corresponding shipping value of strategic hubs and channels will be smaller. As a result of technical progress, however, both geological conditions and natural water depths can be modified, diminishing their relative influence on strategic pivots.

\subsection{Socio-economic distribution}

Although physical geography determines the underlying strategic value of a shipping pivot, whether or not such a location will have value for shipping is a function of global or interregional trade volumes; this means that the formation of a trade network is subordinate to socioeconomic distribution patterns. At the same time, the East Asian countries such as China and India will continue to have a major impact on the mainstream global capitalist economy and on patterns of global capital flows, production and trade (Ray, 2016). Thus, global economic patterns dominated by North America, Europe, and East Asia directly determine the basic distribution of strategic sea pivots. Complementary relationships between these three main regions form the basis of global trade networks, centered on three main arterial global shipping routes, the Far East to Europe and the Mediterranean Sea, North America to Europe and the Mediterranean Sea, and the Far East to North America. Trade between Africa, Latin 
America and the rest of the world has also been continuously strengthened with the rapid economic development of these regions and a complex and concentrated south-south route network has developed. This has also promoted the development of new strategic pivots and advanced the value of existing ones; the ports, channels, and sea areas which are located at the start and end and in transit zones of the three arterial routes outlined above have also created strategic value for their shipping pivots.

At the same time, hinterland economies are other important forces that drive the formation and development of maritime strategic pivots; the level of development and total scale of adjacent economies determine the scale of shipping hubs as evidenced by the fact that Kobe, Busan, Kaohsiung, and Hong Kong have all benefited from the expansion of the Four Asian Tiger economies, and the hinterland of the ports of Antwerp and Rotterdam includes Holland, Belgium, the Rhine-Maas river basin, and Midwest region of Europe.

\subsection{Business organization and technical progress}

Business organization, technical progress and in particular the behavior of enterprises and the evolution of ship technologies have increasingly exerted an influence on the strategic value of ports. Alongside the development of shipping markets, enterprises including those concerned with wharf management have begun to get involved in the organization and control of port development. Shipping enterprises choose their bases and ports of call around the world in order to allocate or recombine shipping resources and organize their routes and frequencies to construct global or regional feeder systems with different statuses and levels. These factors mean that most strategic hubs are also base ports for shipping enterprises. Some wharf enterprises have also invested in the development of their own network at a global scale. A concentration of resources means that hub ports exhibiting great transfer capabilities and with expansive hinterlands can be constructed. This is especially the case in terms of the integration of ports and shipping where coupled resource allocation often occurs between capacity and wharf resources, continuously enhancing strategic value.

Rapid technical improvements in shipbuilding have also increased the value of strategic shipping pivots through the development of larger ship sizes and deeper draught loads. At the same time the higher depth requirements of shipping channels and wharf areas before the bank have led to the functional differentiation of ports, channels, and sea areas: areas with better water depth conditions are more likely to develop into strategic pivots. Alongside the expansion of shipping enterprise networks and increase in 'large-scale ships', the influence of this factor on strategic pivots can be expected to grow.

\subsection{Geopolitical patterns and geopolitical disputes}

In the late 1980s and early 1990s the world geopolitical situation transitioned from a bipolar to a largely unipolar system with a single hegemon and several politically and militarily strong allies, although more recently there is a movement in the direction of multi-polarity with increasingly complex and fierce geopolitical disputes. Global and regional powers continuously pursue political or mineral resource-based interests at the global scale or in important regions, establishing a variety of bases and other types of presence. In this process, key hubs, channels, and straits have become important power bases, especially in the pursuit of geopolitical interests around the world, enhancing the strategic status of the pivots dis- 
cussed in this study.

The influence of and control exercised by major powers on each canal and strait are fully reflective of their geopolitical interests. For example, since Europe started to patrol the seas, globally strategic channels have become a focus of sometimes competitive western interests. After the Second World War, the influence of the USA abruptly increased, reallocating power and control over strategic global pivots, and establishing a governance system through the construction of shipping and military bases. Especially in the Far East which had already become a global shipping center, surrounding countries and world powers vied with each other in the construction and quest to exercise control over strategic channels. China has recently vigorously promoted the Maritime Silk Road strategy. From Pacific island chain strategy to Asia-Pacific rebalancing strategy, the New Silk Road action projects and the recent Indo-Pacific strategy, America sought to tighten its stranglehold on the strategic channels of the Asian-Pacific region (Green et al., 2012). India, Iran and Afghanistan are jointly promoting Southern Silk Road construction in South Asia. Pakistan, Iran and Turkey are working together to construct passageways between the three countries. A complex pattern involving each country of East Asia, South Asia, Central Asia and West Asia is emerging (Chen et al., 2014; Quan et al., 2014; Hou, 2015). The sea area of Southeast Asia has great economic and political significance, facing with many dangers include territorial disputes, nonstate political violence, transnational crime, and environmental degradation (Bradford, 2005). In the South China Sea, China, Taiwan, Malaysia, Philippines, Vietnam and Brunei formed a complex competitive and cooperative geopolitical pattern around territorial disputes and maritime claims (DOD, 2015).

A specific case is the Suez Canal whose strategic significance has seen transitions in control shaped by geopolitical disputes between Egypt, Israel and Turkey locally and a competitive struggle between Britain, France, Germany, Russia and America sometimes openly and sometimes behind the scenes. Controlled by Great Britain for a long time from the colonization of Egypt in 1882 until the 1954 Anglo-Egyptian agreement after the Suez crisis, the UK still exercises considerable influence (Wang, 2005; Shi et al., 2014; Chen et al., 2017). Since the opening of New Sea-route, Portugal, Spain, Netherlands, Britain and the Japanese successively controlled the Strait of Malacca. In 1945 the strait returned to the joint management of three coastal countries, though it is effectively controlled by the USA under the pretext of regional stability, while the three coastal countries invited India to participate in Malacca Strait's defense (Liao et al., 2005; Wang, 2006; Zhang, 2015). The Strait of Gibraltar which connects the Atlantic with the Mediterranean is located between Spain and the small British Overseas Territory of Gibraltar (ceded to Great Britain "in perpetuity" under the Treaty of Utrecht in 1713 but claimed by Spain) in the north and Morocco to the south. Frictions between the United Kingdom and Spain over the status of Gibraltar are frequent, while France, Germany and the Soviet Union were involved in contention over control of the strait from the First World War to the Cold War (Guo, 1982; Shen, 2002; Zhang, 2013). Since the 1980s and the defeat of the US installed Shah of Iran, nuclear and other issues have provoked crises in the relationship between the US and Iran that are also associated with the struggle for control over the Strait of Hormuz 'World Oil Valve'. These geopolitical and geo-economic issues are made more complex by the participation of Israel, the EU, Russia and China (Ren, 2008). In 1904 the US took over the Panama Canal project from the French 
and remained in control of the canal and the surrounding Panama Canal Zone until the 1977 Torrijos-Carter Treaties provided for handover to Panama. After a period of joint American-Panamanian control, in 1999, the canal was taken over by the Panamanian government, but the US reserves the right to intervene militarily (Zhu, 1982).

\section{Conclusions}

A strategic shipping pivot is a spatial concept that has different scale-dependent connotations and can be divided into strategic nodes, channels, and sea areas. Strategic shipping pivots occupy important positions in the global political game as well as in global economic development and military struggles. The shipping strategy of China has evolved from one that initially emphasized the safe transportation of energy to one which safeguards the nation's comprehensive sea rights and interests. Thus, the focus of attention has extended from finding a solution to 'the Sleepy Malacca Bureau' to a strategy focusing on the layout and regulation of multiple points and lines. In this situation it is clearly of great importance to develop a better spatial understanding of global strategic shipping pivots, as this will be of great significance to increasing China's ability to control global shipping resources.

Strategic shipping hubs are port nodes (points) that have dominant positions and exert control over shipping networks. The data collected in this paper show that there are 44 strategic hubs that globally control the spatial organization of shipping networks. The hierarchy of these strategic hubs is spatially differentiated, and they exhibit features of regionalization, diversification, proximity, and symmetry. Strategic channels are narrow linear areas of water. Globally there are seven strategic shipping channels that generally connect two navigation areas. These strategic channels account for a great majority of ship traffic, dominate route organizations, exert obvious control effects on strategic material transportation, and have become focal points for global military and geopolitical struggles, especially in the cases of the Malacca Strait and the Suez Canal which are of the highest global strategic significance. Strategic sea areas are large areas that comprise dense shipping routes where shipping organizations can make various choices. The three key strategic sea areas identified in this study are the Mediterranean Sea, the Caribbean, and the Pacific Ocean adjacent to Southeast Asia. The geographical positions of these regions are special because they include numerous countries, islands, and straits, occupy important strategic positions, are relatively highly fragmented with numerous regimes, are generally located in important navigational areas or at intersections between important economic areas, are connected with, close to, or encompass numerous strategic shipping channels and important strategic shipping hubs, are characterized by dense route organization, and handle a high volume of shipments.

The formation of strategic shipping pivots is affected by a range of factors, especially by physical geography, socioeconomic distributions, business organization and technical progress, and geopolitical patterns and disputes. The analysis shows that these factors can influence, determine, strengthen, or complicate the strategic value of shipping pivots. The research presented in this study reveals the fundamental spatial patterns and mechanisms underlying the formation of global strategic shipping pivots and provides underlying data for China to implement an in-depth go global strategy involving the establishment of stra- 
tegic shipping pivots. The study has also placed a great deal of emphasis on the use of transportation indices and the shipping value of strategic pivots, but has paid less attention to political and military issues. As the computation of these indices and the attachment to them of weights cannot be absolutely objective, more detailed research will be required in the future.

\section{References}

An X P, Han Z L et al., 2000. A study on the formation, evolvement mechanism and development mode of international container load center. Geographical Research, 19(4): 383-390. (in Chinese)

Baird A J, 2005. Optimising the container transhipment hub location in northern Europe. Journal of Transport Geography, 14(3): 195-214.

Bennett M M, 2016. The Silk Road goes north: Russia's role within China's Belt and Road Initiative. Area Development and Policy, 1(3): 341-351.

Bradford J F, 2005. The growing prospects for maritime security cooperation in Southeast Asia. Naval War College Newport Review, 58(2): 63-86.

Cai M J, 2008. The impact of Panama Canal expansion on world shipping. China Maritime, (2): 69-71. (in Chinese)

Chen J Y, 2007. Study on the safety assessment of navigation circumstance. Research on Waterborne Transportation, 3(1): 27-32. (in Chinese)

Chen W L, He C T, 2014. Game of all parties and its economic and trade orientation for Maritime Silk Road. Reform, (3): 74-83. (in Chinese)

Chen X Q, Guan X O, 2017. The past and present of earth's energy neck vessel the Suez Canal. Energy, (9): 90-93. (in Chinese)

Cullinane K, Khanna M, 2000. Economies of scale in large containerships: Optimal size and geographical implications. Journal of Transport Geography, 8(3): 181-195.

Du J, Qiu H, Hu H X, 2014. The safety of the sea lane: An analysis and thinking based on national benefit relativity. Journal of Nanchang University, 45(3): 62-67. (in Chinese)

Fraser D, Notteboom T, 2014. A strategic appraisal of the attractiveness of seaport-based transport corridors: The Southern African case. Journal of Transport Geography, 36: 53-68.

Green M J, Shearer A, 2012. Defining US Indian Ocean strategy. The Washington Quarterly, 35(2): $175-189$.

Guo W B, 1982. The west gate of the Mediterranean: The Strait of Gibraltar. West Asia and Africa, (6): 67-69. (in Chinese)

Hou L M, 2015. Context, position and realization path of Maritime Silk Road in 21st century. Journals of Huaihai Institute of Technology, 13(6): 14-16. (in Chinese)

Hudson R, 2016. Rising powers and the drivers of uneven global development. Area Development and Policy, 1(3): 279-294.

Jia D S, Sun J Y, Luo H B, 2006. Chinese importing oil marine lane safety evaluation and strategy. Journal of Dalian Maritime University, 32(2): 62-66. (in Chinese)

Li B, 2010. A discussion on the status and action of maritime strategy passage. Contemporary World \& Socialism, (2): 90-94. (in Chinese)

Li J, 2010. Overview of world maritime strategy. Decision \& Information, (11): 73-76. (in Chinese)

Li Z, 2010. Impact of the Panama Canal expansion on the bulk shipping market. China Water Transport, (10): 13-13. (in Chinese)

Liang M, Chen R D, 2014. Study on situation and strategy of maritime trade passage. International Economic Cooperation, (11): 79-84. (in Chinese)

Liang J R, 2016. Ocean strategy of the South-Pacific region from the perspective of Maritime Strategy Passages. Forum of World Economics \& Politics, (3): 47-60. (in Chinese)

Liao X N, Li Y H, 2013. The strait of Malacca under the contention between great powers. The World \& Chongqing, (3): 15-16. (in Chinese)

Liu W, Dunford M, 2016. Inclusive globalization: Unpacking China's belt and road initiative. Area Development 
and Policy, 1(3): 323-340.

Notteboom T E, 2006. Traffic inequality in seaport systems revisited. Journal of Transport Geography, 14(2): 95-108.

Quan Y, Wang J, Liu W T, 2014. Strategic conception and construction general plan for Maritime Silk Road in 21 st century. Intertrade, (8): 4-15. (in Chinese)

Ren J J, 2008. Game between America and Iran for the Strait of Hormuz. Leadership Science, (21): 55-56. (in Chinese)

Sun H Y, 2014. The Kra Channel and sea routes: Challenges, meaning, and China's strategic choice. Pacific Journal, 22(7): 90-100. (in Chinese)

Shen Y H, 2002. The last colony: Gibraltar. International Study Reference, (2): 33-36. (in Chinese)

Shi C L, Li X Y, 2013. The impact of the security of the Strait of Hormuz on China's imported oil supply and shipping. China Soft Science, (7): 1-15. (in Chinese)

Shi C L, Li X Y, 2014. The Suez Canal and shipping safety-and China's navigation policy. Pacific Journal, 22(10): 79-90. (in Chinese)

Su X, 2016. Repositioning Yunnan: Security and China's geoeconomic engagement with Myanmar. Area Development and Policy, 1(2): 178-194.

Sun F H, Liu Y J, 2002. "Oceanic Broken Area” in the 21st century. Human Geography, 17(6): 71-76. (in Chinese)

Slack B, 1990. Intermodal transportation in North America and the development of inland load centers. The Professional Geographer, 42(1): 72-83.

Song D W, 2002. Regional container port competition and co-operation: The case of Hong Kong and South China. Journal of Transport Geography, 10(2): 99-110.

United States Department of Defense. The Asia-Pacific Maritime Security Strategy, July 2015 [EB/OL]. http//www. defenselink.mil/

Veenstra A.W, Mulder H.M, Sels R.A, 2005. Analysing container flows in the Caribbean. Journal of Transport Geography, 13(4): 295-305.

Wang C J, 2008. Spatial organization networks of world marine container transportation. Geographical Research, 27(3): 636-648. (in Chinese)

Wang H, 2007. From the Beibu Gulf to the Indochina Peninsula and the Indian Ocean: Building a China-ASEAN strategic passage which serves to avert a "Malacca Dilemma". World Economics and Politics, (9): 47-54, 4. (in Chinese)

Wang L R, 2015. Maritime strategy passage impact on China's economic security and countermeasures. Journal of Economics of Shanghai School, 13(1): 146-156. (in Chinese)

Wang N, 2005. A study of the Suez Canal's security defense issue from the second half of 19th century to early 20th century. Journal of Luoyang Normal University, 24(4): 89-93. (in Chinese)

Wang N, 2006. Superpowers' game for the Strait of Malacca. Leaders'Companion, (2): 20. (in Chinese)

Xin H, 2003. "Shattered Area": The geographical pivot of contemporary international relation. World Regional Studies, 12(1): 100-106. (in Chinese)

Yang H S, 2006. Brief analysis of the Kra Channel's impact on national energy security and development. Pearl River Water Transport, (Suppl.1): 183-184. (in Chinese)

Zhang G G, 2013. The draw lessons from Gibraltar disputation between Britain and Spain. South Reviews, (24): 76-77. (in Chinese)

Zhang J, 2015. Sea-lane security and construction of China's strategic pivots-and security consideration for construction of Maritime Silk Road in 21st century. Journal of University of International Relations, 33(2): 100-118, 159-160. (in Chinese)

Zhao F, Lou X C, 1998. Gullet of the marine passages: Strait. Hydrographic Surveying and Charting, (1): 40-47. (in Chinese)

Zheng Z Y, Zhang J Z, Dong W F et al., 2012. Deployment of China's strategy passages at sea. Navigation of China, 35(2): 55-59. (in Chinese)

Zhu L S, 1982. The Panama Canal negotiation and new treaty between Panama and America. World History, (4): 54-62. (in Chinese) 